\title{
WORLD TRADE AND
}

\section{GLOBAL INTEGRATION IN}

\section{PRODUCTION PROCESSES}

\section{A RE-ASSESSMENT \\ OF IMPORT DEMAND EQUATIONS}

by Ray Barrell

and Stephane Dées 
E UROPEAN CENTRAL BANK

\title{
WORKING PAPER SERIES
}

N0. 503 I JULY 2005

\author{
WORLD TRADE AND \\ GLOBAL INTEGRATION IN \\ PRODUCTION PROCESSES
}

\author{
A RE-ASSESSMENT \\ OF IMPORT DEMAND \\ EQUATIONS '
}

by Ray Barrell ${ }^{2}$

and Stephane Dées ${ }^{3}$

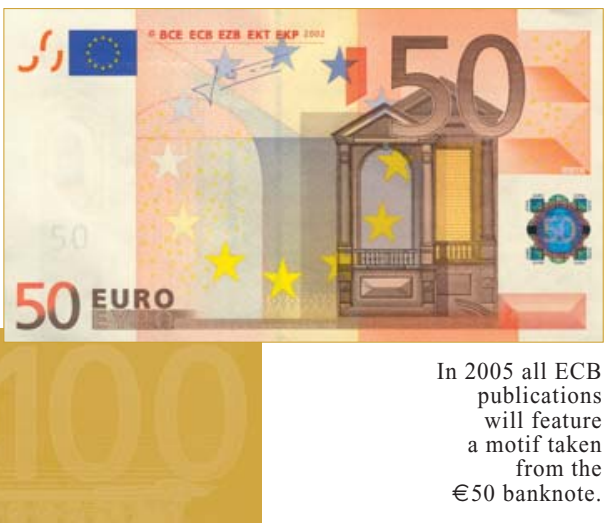

This paper can be downloaded without charge from http://www.ecb.int or from the Social Science Research Network electronic library at http://ssrn.com/abstract_id =750764.

I The paper benefited from comments by Filippo di Mauro, Pavlos Karadeloglou and an anonymous referee. The views expressed in this paper are those of the authors and do not necessarily reflect the position of the European Central Bank. 2 National Institute of Economic and Social Research (NIESR), 2 Dean Trench Street, Smith Square, London SWIP 3HE, 


\section{(C) European Central Bank, 2005}

\section{Address}

Kaiserstrasse 29

60311 Frankfurt am Main, Germany

\section{Postal address}

Postfach 160319

60066 Frankfurt am Main, Germany

Telephone

+496913440

\section{Internet}

http://www.ecb.int

Fax

+496913446000

Telex

411144 ecb d

All rights reserved.

Reproduction for educational and noncommercial purposes is permitted provided that the source is acknowledged.

The views expressed in this paper do not necessarily reflect those of the European Central Bank.

The statement of purpose for the ECB Working Paper Series is available from the ECB website, http://www.ecb.int.

ISSN 1561-0810 (print)

ISSN 1725-2806 (online) 


\section{CONTENTS}

Abstract 4

Non-technical summary 5

1 Introduction 7

2 Theoretical background 10

3 Empirical evidence 17

3.1 Import and FDI trends over the last 20 years $\quad 17$

3.2 The empirical approach 20

3.3 Benchmark values for income and price elasticities for import equations

3.4 Results including FDI in the import equations

4 Conclusion

References

Appendix

European Central Bank working paper series 


\begin{abstract}
It is common to observe that demand elasticities in trade equations for imports are implausibly large, and that they differ between countries. Both of these present us with problems, as they imply trade will rise without bound as a proportion of GDP. The research reported here looks for alternative empirical evidence of possible factors driving the increase in trade as a proportion of GDP. We show that the inclusion of the ratios of outward and inward FDI to GDP as additional openness and globalisation indicators appear to remove the spurious accuracy with which we are measuring demand elasticities.
\end{abstract}

Keywords: International trade; FDI

JEL codes: F10, F23. 


\section{Non-technical summary}

Almost all discussions of globalisation and the internationalisation of production highlight the growing share of trade in output, one of the most striking features of the world economy since World War II, and even more in the last twenty years. Since 1980, world real imports have grown faster than world real GDP. Studies of import demand relationships suggest that the income elasticity of import demand is well in excess of one in all countries, and frequently above two. This could be a temporary phenomenon, and the strong observed relationship between income growth and import growth could disappear. If it did not disappear then as imports would continue to grow faster than income and quite quickly (almost) all income would be spent on imports in all countries, and (almost) all output would be exported. Although this might happen in small very open economies such as Singapore it seems an unlikely outcome for all countries in the world. Indeed, it is probably the case that other factors that are currently growing in line with income are the true drivers of rising import penetration.

The research reported here looks for factors that might increase the level of trade over time. These factors would need to be such that their effect reached a maximum at some point before import penetration reached $100 \%$, and hence we should look for openness or technology indicators, for instance, that are bounded, but which can grow significantly over long periods of time.

Over the last 25 years new explanations for the level and growth of trade have been developed, and these 'new trade theory' approaches have stressed the role of relocation in explaining increased levels of imports and exports. Changes in the variety and quality of goods are seen as central to explaining these trends, and they are also at the centre of our argument. Increases in the level of FDI represent increases in the capacity of a country to produce a greater variety of 
goods, especially in a world of differentiated products. More firms means more products, and hence a greater variety of goods.

In this paper we investigate import demand in a large range of countries. In a first step, we estimate import demand equations with traditional determinants (domestic demand and relative prices). The results show that it is statistically impossible to impose common demand and price elasticities, and the observed demand elasticity remained high. In a second step, we estimate an equation that includes the ratios of outward and inward FDI to GDP as additional openness and globalisation indicators. These variables appear to remove the spurious accuracy with which we were measuring demand elasticities. The variety of coefficients and effects, which differ between countries, means that we cannot statistically justifiably impose a common set of coefficients on inward and outward FDI in all countries. However, overall inward and outward FDI appear to raise imports. Moreover, it is possible to impose common income effects once we allow for inward and outward FDI as a determinant of import propensities, and the income elasticity of demand is reduced to 1.24 , well below the estimated elasticities we observe either in single country regressions or in those derived in panels when we do not include inward and outward FDI. Hence we demonstrate that the inclusion of the ratio of outward and inward FDI as a percent of GDP resolves most of these puzzles we face with import demand.

However, we would argue that there is need for further research to understand both the diversity of FDI effects between countries and the role of other forces driving globalisation such as the formation of regional trading systems, which raise imports as a proportion of GDP. 


\section{INTRODUCTION}

Almost all discussions of globalisation and the internationalisation of production highlight the growing share of trade in output. Indeed, trade's growing share in the world economy is one of the most striking features of the world economy since World War II, and even more in the last twenty years. Since 1980, world real imports have grown faster than world real GDP. Most countries, no matter their types - small and large, rich and poor, fast-growers and slow growers have experienced such developments (see chart below).

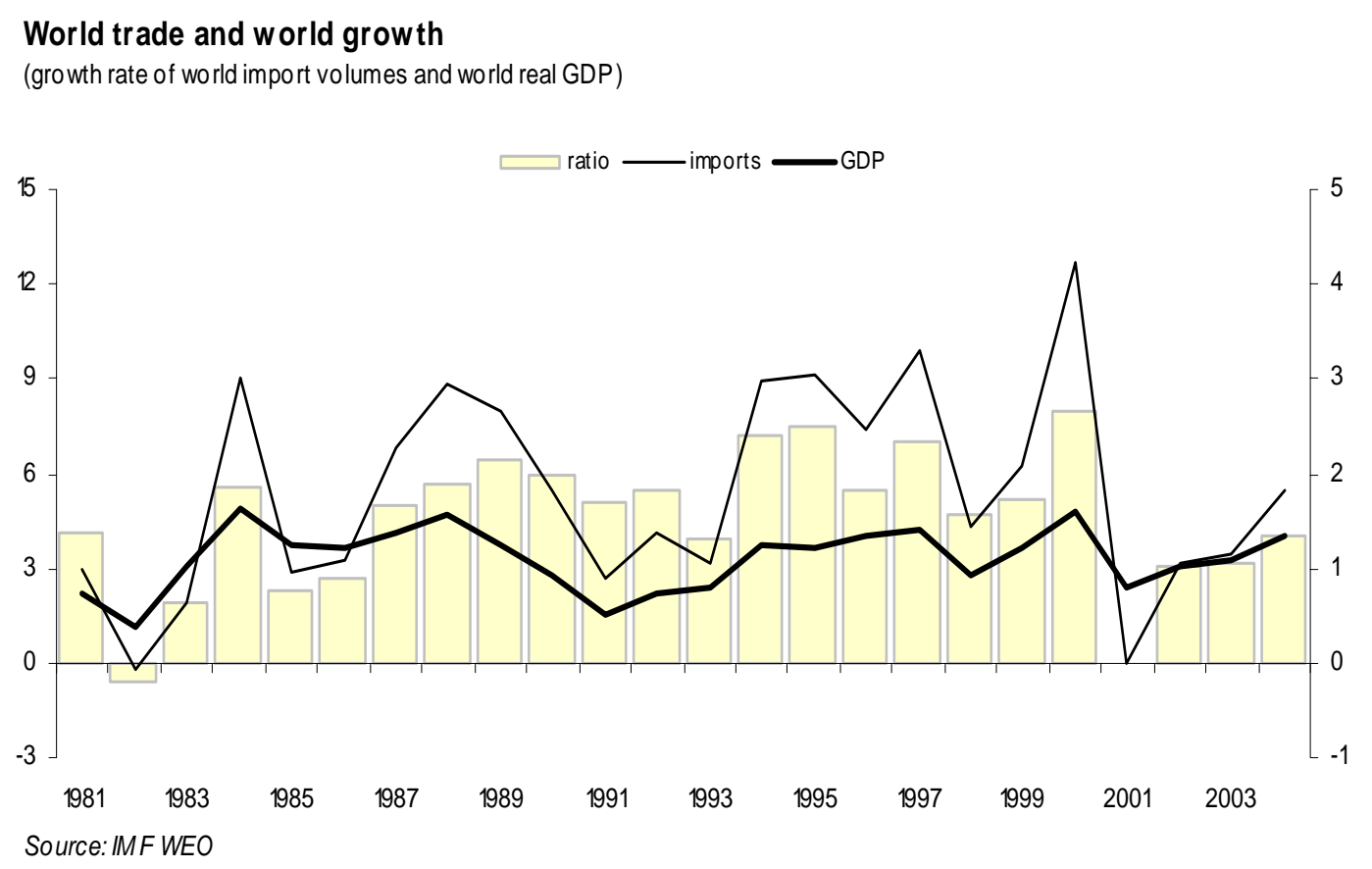

Growth rates on $L H$ axis, ratio of $R H$ axis

Studies of import demand relationships summarised in Barrell and te Velde (2002) suggest that the income elasticity of import demand is well in excess of one in all countries, and frequently above two. This could be a temporary phenomenon, and the strong observed relationship between income growth and import growth could disappear. If it did not disappear then as imports would continue to grow faster than income and quite quickly (almost) all income would be spent on imports in all countries, and (almost) all output would be exported. Although this might happen in small very open economies such as Singapore it seems an unlikely outcome for 
all countries in the world. Indeed, it is probably the case that other factors that are currently growing in line with income are the true drivers of rising import penetration. If this were the case then we cannot expect the income elasticity of demand in relationships of this nature to remain stable. The standard empirical models based on traditional comparative advantage theory discussed in Barrell and te Velde (2002) appear unable to explain the excess growth in imports. The research reported here looks for alternative empirical evidence of possible factors driving the increase in trade as a proportion of GDP. In particular, we need to look for factors that might increase the level of trade over time. These factors would need to be such that their effect reached a maximum at some point before import penetration reached $100 \%$, and hence we should look for openness or technology indicators, for instance, that are bounded, but which can grow significantly over long periods of time.

Many factors could be at work, and Barrell and te Velde (2002), for instance look for a role for regional trade and competition liberalisation. Such programmes reduce barriers to trade and hence can be expected to raise the level of imports (and hence exports) for any level of output and income. They do find a role for the Single Market Programme (SMP) in Europe in expanding the level of imports within Europe, and this is clearly associated with the reduction in barriers to trade and to competition within the Single Market. However, Barrell and te Velde (2002) find that many of the impacts of liberalisation are captured by increased foreign direct investment (FDI) within Europe. They argue that the process of liberalisation has induced significant bilateral cross border movements of production, and that this has been accompanied by an increase in imports into both home and host countries. The FDI indicators 'replace' the Single Market indicators, in that they represent the true driving force increasing trade, rather than acting as proxies for it. Similar trade and capital movement liberalisation has taken place within North America under NAFTA, and to a lesser extent in Mercosur and in the APEC open region, and these can be expected to have increased the level of trade. Barrell and Choy (2003) argue 
that increased FDI has been a major feature in increasing integration within Europe, and that it is the removal of the barriers to the movement of productive capital that has been particularly important in reshaping the pattern and scale of trade within Europe. They also argue that the importance of FDI in the integration process has increased in the last few years

Over the last 25 years new explanations for the level and growth of trade have been developed, and these 'new trade theory' approaches have stressed the role of relocation in explaining increased levels of imports and exports. Krugman (1989) for instance points out that rapidly growing countries tend to have rapidly growing exports and hence rising real exchange rates. He suggests that such trends need explaining, as real exchange rates should be stationary in the long run. Changes in the variety and quality of goods are seen as central to explaining these trends, and they are also at the centre of our argument. Increases in the level of FDI represent increases in the capacity of a country to produce a greater variety of goods, especially in a world of differentiated products. More firms means more products, and hence a greater variety of goods. Of course direct indicators of regional trade agreements and tariff barrier measures could be used as well. The former are often rather crude indicators, although Barrell and te Velde (2002) do use ‘aquis signing' measures of SMP intensity. However, these do not work as well as FDI. In addition, the genuine reduction of barriers is normally accompanied by increases in FDI. Measuring tariff and non-tariff barriers is particularly difficult, especially as it is the non-tariff ones that appear to have been more effective in the last two decades. Barrell and Pain (1999) argue that anti-dumping measures induce Japanese FDI in Europe, and this forms a substitute for imports. Clearly, the impacts of trade liberalisation and FDI on import penetration are more complex than the patterns discussed here, and merit further work.

In the second section of this paper we discuss the implications of new trade theory for import equations, and conclude that we cannot draw unambiguous implications. In the third section we look at the estimation of trade equations based on new trade theory, where the effects of FDI are 
present. We might expect that increased outward direct investment would in general increase imports, as domestic production for domestic consumption shifts to being foreign production for domestic consumption. The impact on imports of inward FDI is less clear, as it may either substitute for imports or induce an increase in imports in order to enable production for export to foreign markets. Hence our general priors are that FDI has increased trade, but that its effects can be diverse.

\section{THEORETICAL BACKGROUND}

The changing nature of the world economy, and in particular changing technology and the removal of barriers to trade have meant that the factors affecting aggregate export and import demand have been changing over time. There have been a number of attempts to include theoretically justifiable additional variables in trade equations, and Pain and Wakelin (1998) and Barrell and te Velde (2002) present evidence that adequate and stable export and import demand models can be constructed. It appears to be of crucial importance to include non-price factors and relocation effects. Recent developments in trade theory have extended our understanding of the determinants of trade, and the introduction of imperfect competition into such models has allowed us to look at the determinants of the number of firms in an economy, and hence at its ability to export and need to import.

Krugman (1989) claims that fast-growing countries expand their share of world markets not by reducing the relative price of their goods but by expanding the range of products they produce as their economies grow. Simple empirical studies give higher export demand elasticities and low import demand elasticities to fast growing countries than to slow growing ones, and suggest that there is a difference in income elasticities of the demand for imports and exports among countries with different growth rates. This might lead us to think that the rate of growth in output would affect the current balance, and hence the equilibrium level of the real exchange rate. 
However, if we allow for this increased range and quality of products in import demand models it is not clear whether these differences are persistent.

The theory of international trade developed in the 1980s acknowledged the influence of nonprice factors, such as innovation, and of the importance of the relative quality and range of domestically produced and imported products, especially in manufactures. Fagerberg (1996) points to the importance of technology affecting international competitiveness, both theoretically and empirically. He claims that there may be some heterogeneity among countries in the way technology and other variables affect competitiveness, but that the evidence so far prevents us from drawing strong conclusions.

The role of multinational corporations has also been discussed, for instance in Krugman (1995) and they have a major role in both the new trade theory and the new economic geography. It is useful to view the multinational corporation as essentially a multi-plant firm choosing where to locate its plants. This decision will depend on the economies of scale within the plant as compared to those at the level of the firm, and also on the costs of moving goods from a plant to a market. These costs will depend on distance and on barriers to trade produced by national borders. As firm-based economies of scale become more common with the use of information and computer-based technologies, we might expect to see more multi-plant (and therefore multinational) firms. In addition, if goods become 'lighter' ${ }^{1}$ and barriers to cross border location fall then again, we might expect to see more multi-plant and multi-national firms

There is now a large empirical literature on the relation between FDI and trade (see e.g. UNCTAD, 1996, OECD, 2002). However, theoretical models do not automatically lead to a clear answer as to whether FDI and trade are complements or substitutes. In the Hecksher-Ohlin comparative advantage model in Mundell (1957), international trade and international factor

\footnotetext{
${ }^{1}$ By this we mean transport costs per unit of real value fall. This is particularly important in service industries where communication costs have fallen markedly, and this has led Coyle (1998) amongst others to discuss the weightless economy.
} 
mobility are substitutes, and capital is an homogenous factor input in this model. As Markusen (1983) has shown, this substitution relationship is based on the assumption that factor endowments alone are the basis for trade and countries are assumed to be otherwise identical. If the basis for trade reflects other difference between countries, such as technology, it can be shown that a complementary relationship may exist between FDI and trade. The variety of possible links between trade and FDI cannot be ignored, and hence we may not expect to find that they are the same in all countries.

It is widely acknowledged that the quality and variety of products and FDI affect trade within the monopolistic competition models employed by the new trade theory. This approach builds on Dixit and Stiglitz (1977), which posits the existence of economies with a large number of monopolistically competitive firms. Each firm produces a different product under increasing returns to scale, and faces a downward sloping demand curve. It is useful to assume that the economies of scale are at the level of the firm rather than at the level of the plant, and we assume that each firm operates a number of plants all at the minimum cost on a $U$ shaped cost curve ${ }^{2}$. If the firm grows, the number of plants expands through a cloning process. The number of firms indexes the variety of products produced, and the variety of products will depend on factors such as the level of R\&D and these have to be included in the trade relations we study.

We can show that trade can be indexed on the number of firms in a simple framework where we distinguish between consumption in the domestic and in the foreign market, and between production for the domestic market and for the foreign market ${ }^{3}$. Let us first set up a world in which there is trade but no foreign direct investment. Suppose that preferences of a representative consumer in each of two countries, domestic $(d)$ and foreign $(f)$, are such that utility of differentiated goods enter symmetrically in a constant-elasticity-of-substitution (CES) form :

\footnotetext{
${ }^{2}$ See Barrell and Pain (1997) for a discussion of the importance of knowledge-based assets in multiplant firms engaged in foreign trade and investment.

3 This approach follows that of Magnier and Toujas-Bernate (1994)
} 


$$
\begin{aligned}
& U_{d}=\left\{\sum_{i=1}^{n+m} q_{i}^{\vartheta}\right\}^{1 / \vartheta} \quad 0<\vartheta<1 \\
& U_{f}=\left\{\sum_{k=1}^{m+n} q_{k}^{\vartheta}\right\}^{1 / \vartheta} \quad 0<\vartheta<1
\end{aligned}
$$

Firm $i$ produces good $i$ and the total number of domestically differentiated goods is $n$. There are $m$ differentiated products produced abroad, and domestic consumers buy all goods $n+m$ and their utility is $\mathrm{U}_{\mathrm{d}}$, with a similar definition for foreign consumers. It is convenient to assume that consumers at home and abroad have the same taste parameter $\theta$. The number of products is large, but it is finite because of fixed costs in production. As $n$ and $m$ are large we can say that production of one good has little effect on other goods. The free-entry condition will drive profits to zero. New firms will not contest markets for existing goods, because they can always start the production of a new good. After maximising consumer's utility, the demand for product $i$ (or $k$ ) can then be approximated by (see Tirole, 1988)

$$
q_{i}=\kappa p_{i}^{-1 /(1-\vartheta)}, \kappa>0
$$

We can distinguish between two sets of producers, domestic and foreign, serving each of the two markets, domestic and foreign, and we can aggregate these sets in various ways. Each firm has (the same number of) multiple plants, some dedicated to domestic production, other for export production. We first consider those who supply the domestic market. There are $\mathrm{n}_{\mathrm{d}}$ domestic located plants each charging price $\mathrm{p}_{\mathrm{d}}$ and supplying $\mathrm{q}_{\mathrm{d}}$ to the domestic market, and there are $\mathrm{m}_{\mathrm{d}}$ foreign located plants each charging price $\mathrm{p}_{\mathrm{f}}$ and supplying $\mathrm{q}_{\mathrm{f}}$. to the domestic market. Suppose that there is a specific $\kappa$ facing each aggregated producer supplying the domestic market. The pattern of demand across domestic producers and foreign producers in the domestic market can be described by the following share equation 


$$
S_{D O M}=\frac{\sum_{i=1}^{n_{d}} p_{d i} q_{d i}}{\sum_{i=1}^{n_{f}} p_{f i} q_{f i}} \equiv \frac{n_{d} p_{d} q_{d}}{m_{d} p_{f} q_{f}}=\frac{n_{d} \kappa_{d}}{m_{d} \kappa_{f}}\left(\frac{p_{d}}{p_{f}}\right)^{-\vartheta /(1-\vartheta)}
$$

representing the market share of domestic firms relative to the share of imported goods. This clearly depends on the relative variety of products in the two producing countries which in turn depends on relative R\&D and other factors that affect technology. If, for instance, technology improvements in foreign countries rise faster than at home, then this may be reflected by a decrease in the ratio $n_{d} / m_{d}$, as more foreign firms each with the standard number of plants are created in order to produce the new varieties generated by R\&D. This implies that firms located abroad capture a larger share of the home market.

In this two-country model, we can look at the exporting firms in the same way. Let us assume that there are $\mathrm{n}_{\mathrm{f}}$ domestic identical plants each charging price $\mathrm{px}_{\mathrm{d}}$ and supplying $\mathrm{qx}_{\mathrm{d}}$ to the foreign market and $\mathrm{m}_{\mathrm{f}}$ foreign identical plants each charging price $\mathrm{px}_{\mathrm{f}}$ and supplying $\mathrm{qx}_{\mathrm{f}}$ to the same market. Suppose again that there is a specific $\kappa$ for each aggregated producer. Then, demand can be described by the following export share equation representing the export market share of domestic firms relative to the share of foreign located firms in the same market:

$$
\text { exshareDom / For }=\frac{\sum_{k=1}^{n_{f}} p x_{d k} q x_{d k}}{\sum_{k=1}^{m_{f}} p x_{f k} q x_{f k}} \equiv \frac{n_{f} p x_{d} q x_{d}}{m_{f} p x_{f} q x_{f}}=\frac{n_{f} \kappa_{d}}{m_{f} \kappa_{f}}\left(\frac{p x_{d}}{p x_{f}}\right)^{-\vartheta /(1-\vartheta)}
$$

Domestic production in the first country is $n_{d}+n_{f}$ made up of producers for the home market and exporters, whilst the second country has domestic production of $\mathrm{m}_{\mathrm{d}}+\mathrm{m}_{\mathrm{f}}$ made up of exporters to the first country and domestic producers for this market. Both domestic producers and producers for export can be owned by the other country, and can be denoted with the obvious subscripts, as 
above. In this framework, exports and outward FDI are always substitutes, and faster technology development at home raises the export share.

However, production for export is not the only way the owner of knowledge based assets can obtain market share abroad. Some of the cloned plants can be located in the market they serve. For instance, an increase of inward FDI may be translated into an increase in $n_{d}$ by $n_{d, f}$ plants producing domestically but owned by foreign residents leading to a smaller share captured by foreign located plants. ${ }^{4}$ Conversely we can argue that it is possible that outward FDI could reduce the quality and variety of products produced at home and hence potentially raise imports from the $m_{\mathrm{f}, \mathrm{f}}$ that choose to locate abroad. In this simple framework FDI and trade are always substitutes (or unrelated), and they are never complements ${ }^{5}$.

The simple framework above does not allow for heterogeneity between domestic or foreign located firms, or between domestic and foreign-owned firms in the domestic market, and does not differentiate between product and input markets. Let us now introduce intermediate goods, which can vary from managerial input associated with the product specific technology to physical inputs into the production process. We can assume that all plants in the domestic market need intermediate inputs and that foreign-owned plants (and only foreign owned plants) in the domestic market $\left(n_{\mathrm{d}, \mathrm{f}}\right)$ need to get their intermediate inputs from abroad for production of their goods. ${ }^{6}$ The intermediate good may reflect country specific goods characteristics that may be the result of government regulation. Neither profits nor net output are affected by the use of the intermediate.

\footnotetext{
${ }^{4}$ One needs to be careful as inward FDI is a financial flow and only part of this is fixed investment and/or greenfield investment, whereas the rest represents a change in ownership. Such a change in ownership upgrades new products, and leaves the number of products unchanged. However, changes to the model to incorporate product quality are trivial.

${ }^{5}$ However, it could leave imports unchanged if the outward FDI were taking new products and processes with it to serve completely new markets.

${ }^{6}$ Initially this could be capital goods to set-up a plant abroad, but later this could simply represent an 'import-bias' favouring inputs from abroad.
} 
Suppose that each consumer good produced by (foreign-owned or domestic-owned) plants in the domestic market require the equivalent of $\delta$ units of consumer goods. Domestically purchased and used intermediates do not enter the utility of the individual as they are part of the final product, which is measured on a net, or value added basis. However, imported (and exported) intermediate products are recorded differently although they also only enter gross output. It is possible that intermediate inputs can exceed the value of net output, although they cannot exceed gross output. Imports are now made up of final goods, $\mathrm{m}_{\mathrm{d}}$ and intermediate goods, $\delta \mathrm{n}_{\mathrm{d}, \mathrm{f} \text {. }}$ We can write total imports as $m_{d}+\delta n_{d, f}$. Hence inward FDI, which increases $n_{\text {d.f }}$ by one plant but reduces direct imports by one unit can raise or reduce imports depending on whether $\delta$ is larger or smaller than one ${ }^{7}$.

We can further suppose that firms may decide to locate a cloned plant abroad to export to the home market in order to take advantage of lower costs or specific regulation advantages ${ }^{8}$. Thus, plants $n_{\mathrm{i}, \mathrm{j}, \mathrm{k}}$ are located in market $i$, are owned by country $j$, and produce for market $k$ such that $i$, $j, k$ are home $(d)$ or abroad $(f)$, and hence there are 8 different type of plants. Plants in $d$ owned by country $f$ import intermediates from country $f$ and firms $n_{\mathrm{f}, \mathrm{d}, \mathrm{d}}$ are plants owned by home and produce for home, but since they are located in country $f$ they add to imports, but also raise exports as they require intermediate inputs to serve the domestic market. It is easy to show that the market share of domestic plants over total imports becomes (in volume terms)

$$
s_{D O M}=\frac{n_{d, d, d}+n_{d, f, d}}{n_{f, f, d}+n_{f, d, d}+\delta\left(n_{d, f, d}+n_{d, f, f}\right)}
$$

Inward investment can raise imports, reduce them or leave them unchanged depending on the type of investment. For instance, a new foreign plant created by merger or acquisition will raise imports in country $d$ as it raises imports of intermediate goods as long as $\delta>0$, whereas a relocation of a plant from the foreign country where it previously exported to home will reduce

\footnotetext{
${ }^{7}$ We would posit that the larger the country the smaller the proportion of intermediate products needed for a unit of exports, but we do not include that feature here.

${ }^{8}$ This requires a slight change in notation to allow for 3 subscripts.
} 
imports as long as $1>\delta$. Other possibilities, including the different effects of outward investment, are clearly possible.

Our understanding of the relationship between trade and FDI cannot depend on theory alone, and we need to undertake statistical analysis of the relationship. This can be done on firm level data, but this approach has to allow for both birth and death of firms, and it is best combined with case studies, as in Griffith (1999). We think that the analysis of aggregate data can reveal important patterns and aid in our understanding of the economy.

\section{EMPIRICAL EVIDENCE}

\subsection{Import and FDI trends over the last 20 years}

Before presenting our empirical results, we briefly discuss the trends in imports and FDI in our chosen sample of countries. Our empirical research is based on a database of 22 countries (see Table $1^{9}$ ), representing about $80 \%$ of world trade, over 1982 to 2002 (on a quarterly basis). The data used are from the IMF International Financial Statistics (IFS). We construct FDI stock variables by taking annual stock data in 1980 from UNCTAD and derive the quarterly data by interpolation using flow data in IFS (see UNCTAD, 2003 for a description of the method), and we then divide these by annualised GDP. The figures we derive for these FDI stocks in terms of GDP are consistent with the published annual UNCTAD shares, and the results obtained are not significantly different from those in the UNCTAD World Investment Report.

\footnotetext{
${ }^{9}$ In the empirical part, Malaysia has been replaced by Brazil owing to data availability problems.
} 
Table 1 - Leading importers in world merchandise trade, 2002

\begin{tabular}{rlrr} 
(Billion dollars and percentage) & \multicolumn{1}{c}{ Importers } & Value & Share \\
\hline Rank & United States & 1202.4 & 18.0 \\
\hline 1 & Germany & 493.7 & 7.4 \\
3 & United Kingdom & 345.3 & 5.2 \\
4 & Japan & 337.2 & 5.0 \\
5 & France & 329.3 & 4.9 \\
6 & China & 295.2 & 4.4 \\
7 & Italy & 243.0 & 3.6 \\
8 & Canada & 227.5 & 3.4 \\
9 & Netherlands & 219.8 & 3.3 \\
10 & Hong Kong, China & 207.2 & 3.1 \\
11 & Belgium & 197.4 & 2.9 \\
12 & Mexico & 173.1 & 2.6 \\
13 & Spain & 154.7 & 2.3 \\
14 & Korea, Republic of & 152.1 & 2.3 \\
15 & Singapore & 116.4 & 1.7 \\
16 & Taipei, Chinese & 112.6 & 1.7 \\
17 & Switzerland & 83.7 & 1.3 \\
18 & Malaysia & 79.9 & 1.2 \\
19 & Austria & 78.0 & 1.2 \\
20 & Australia & 72.7 & 1.1 \\
21 & Sweden & 66.2 & 1.0 \\
22 & Thailand & 64.7 & 1.0 \\
& Total sample & 5252.1 & 78.5 \\
\hline
\end{tabular}

Table 2 - Stocks of FDI as a percentage of GDP

\begin{tabular}{lcccccccc}
\hline \hline & \multicolumn{4}{c}{ Inward FDI } & \multicolumn{5}{c}{ Outward FDI } \\
& av. 70s & av. 80s & av. 90s & av. 2000-02 & av. 70s & av. 80s & av. 90s & av. 2000-02 \\
\hline US & 1.7 & 4.7 & 7.7 & 15.5 & 2.7 & 5.2 & 9.6 & 15.8 \\
Germany & 3.7 & 4.6 & 5.4 & 18.2 & 4.1 & 8.3 & 15.0 & 28.0 \\
UK & 7.9 & 13.3 & 24.5 & 42.4 & 9.1 & 19.2 & 34.9 & 72.9 \\
Japan & 0.3 & 0.3 & 0.4 & 1.3 & 0.4 & 0.9 & 2.4 & 3.3 \\
France & 3.3 & 5.5 & 13.3 & 23.2 & 3.2 & 5.9 & 18.6 & 41.2 \\
China & n.a. & 2.3 & 14.1 & 30.5 & n.a. & 0.2 & 1.6 & 2.3 \\
Italy & 3.0 & 3.3 & 5.0 & 7.1 & 2.3 & 3.3 & 6.3 & 9.9 \\
Canada & 18.4 & 19.4 & 20.6 & 24.3 & 17.2 & 18.7 & 20.6 & 24.5 \\
Netherlands & 8.6 & 15.7 & 31.1 & 60.7 & 14.1 & 33.4 & 57.7 & 91.4 \\
Hong Kong & n.a. & 497.3 & 190.9 & 257.1 & n.a. & 1.5 & 30.9 & 247.1 \\
Belgium & 10.6 & 17.5 & 43.8 & 83.9 & 8.7 & 11.8 & 33.1 & 67.8 \\
Mexico & 8.7 & 10.5 & 15.3 & 22.8 & 0.1 & 0.1 & 0.7 & 1.6 \\
Spain & 0.6 & 5.2 & 15.0 & 22.6 & 0.3 & 2.9 & 5.0 & 22.0 \\
Korea & 1.6 & 2.2 & 3.9 & 9.1 & 0.3 & 1.3 & 4.7 & 8.4 \\
Singapore & 61.3 & 71.7 & 79.3 & 136.1 & 29.3 & 30.5 & 34.6 & 95.0 \\
Taiwan & n.a. & 5.3 & 5.4 & 9.1 & n.a. & 0.7 & 6.1 & 12.7 \\
Switzerland & 8.7 & 10.8 & 20.9 & 40.0 & 8.7 & 13.0 & 39.9 & 84.5 \\
Austria & 3.7 & 4.9 & 8.2 & 16.8 & 2.1 & 3.2 & 7.3 & 13.3 \\
Australia & 14.4 & 15.5 & 25.0 & 31.3 & 3.2 & 4.0 & 12.6 & 28.1 \\
Sweden & 2.6 & 4.1 & 17.4 & 60.3 & 3.4 & 10.2 & 31.2 & 62.4 \\
Thailand & 4.1 & 4.8 & 13.0 & 26.6 & 0.1 & 0.1 & 1.3 & 2.1 \\
Brazil & 9.6 & 9.4 & 10.9 & 26.2 & 8.6 & 8.6 & 8.7 & 9.4 \\
\hline
\end{tabular}


Table 2 shows the trends in the shares of FDI stocks in GDP for different periods. This table features a few interesting observations. FDI stocks as a percentage of GDP have increased in all the countries of our sample, and only inward FDI as a percent of GDP fell, and then only in two countries, Hong Kong and Brazil, and across only one early time divisions. Net inward FDI as a percent of GDP is ultimately bounded by the value of the assets that generate GDP. However, it is clear that none of the countries we observe have reached this ratio, which we might put at 300 per cent of GDP, or the total value of the domestic capital stock ${ }^{10}$. As a result it is clear that neither inward nor outward FDI stocks as a percent of GDP are stationary over the period we are investigating, and as they started at such low levels, we would not have expected them to display this property. In general, we would expect to see the import share in GDP to rise, whilst inward and outward FDI increase, but as our theoretical discussion makes clear there are circumstances where we might observe declines in import penetration. The stock of FDI relative to GDP cannot grow without bound, and hence, once it has reached its upper bound it cannot increase the ratio of import to total final expenditures any further. Hence import penetration is bounded, whilst if we used the level of real FDI our equations would not display this characteristic.

The increase in the FDI to GDP ratio was particularly large in the 1990s and in the beginning of the $21^{\text {st }}$ century as liberalisation of goods and financial markets in both Europe and North America increased. It is interesting to note from the table that in small open economies, FDI stocks (inward and outward) represent a large proportion of GDP (e.g. Netherlands, Hong Kong, Singapore, Switzerland, Sweden). The table also suggests that among the large industrial countries, investment abroad tends to be higher than inward investment. However, the latter has increased substantially in the 1990s and over the period 2000-2002. In contrast, the level of inward FDI in Japan has remained relatively low, despite a noticeable increase in outward FDI

\footnotetext{
${ }^{10}$ Even if this net ratio forms an upper bound, gross stocks can exceed this percentage of GDP. Outflows of FDI create financial assets that can be owned by foreign investors in the country in question. Hong Kong is the only clear example of this in our sample.
} 
from the 90s. In addition, among the developing countries, Mexico, Thailand, Brazil and China attract much more FDI than they make abroad. Hence, in general, the main industrialised countries tend to have a net stock of outward FDI, while the developing countries have a net stock of inward FDI.

\subsection{The empirical approach}

We first estimate simple specifications including demand and relative price terms, in order to estimate "standard" income and price elasticities at the world level. We then include inward and outward FDI in order to capture globalisation effects and global integration in production processes. Based on panel data techniques, the approach allows us to test the presence of differences in parameters across countries.

Modern panel data techniques allow us to investigate common trends and relationships between countries without necessarily assuming that all countries display the same characteristics ${ }^{11}$. We may treat each country we study as a member of the cross section we analyse. We presume that within each country there is a long-run equilibrium relationship ${ }^{12}$. It is common to estimate models of individual countries with some dynamics of adjustment. These adjustment processes may differ for reasons associated with institutions that change the costs of adjustment, and more flexible economies may adjust more rapidly. Pesaran and Smith (1995) show that the assumption that all members of a group can be included in a common panel with common dynamics can be very misleading. If the dynamics of adjustment differ between countries and we assume that they are common in estimation, then the resulting dynamics may be biased, and it is possible that the estimated speed of response in a pooled model is slower than that observed in any of the members of the panel. In order to avoid these problems, we need to estimate individual country

\footnotetext{
${ }^{11}$ Hsiao (2003) discusses modern panel data analysis in dynamic models. The fundamental propositions on which we build come from Pesaran and Smith (1995)

${ }^{12}$ Each country needs to display a cointegrating relationship and the members of the panel need to share common characteristics in order that we can demonstrate that we have panel cointegration. It is very useful that there are two dimensions of equilibrium adjustment to analyse in a panel. Countries that are away from their own equilibrium can be presumed to adjust, and those that are not at a shared equilibrium will also be adjusting to that. Pesaran, Shin and Smith (1999) discuss panel cointegration in detail.
} 
equations and test if a common dynamic specification can be imposed. Our objective is to uncover the largest defendable set of commonalities.

\subsection{Benchmark values for income and price elasticities for import equations}

We need to derive some benchmark values for income and price elasticities of the import equations for the countries of the sample. We adopt a common model for each country and estimate the equations with no common parameters. Our data sets differ in length between countries, and in order to utilise the maximum information on all of them we set them up as a synthetic unbalanced panel. Hence all countries enter the SURE regressions with the same data periods, but the parameter estimates and ' $\mathrm{t}$ ' statistics depend only on the maximum data set available in each country. This setup allows us to impose cross equation parameter restrictions within SURE to test for commonalities. The country-specific equations follow the specification:

$$
\begin{aligned}
\Delta \log \left(M_{i, t}\right) & =\alpha_{i}+e c t_{i}\left(\log \left(M_{i, t-1}\right)-a_{1, i} \log \left(T F E_{i, t-1}\right)-a_{2, i} \log \left(R P_{i, t-1}\right)\right) \\
& +\sum_{j} \beta_{i, j} \text { dynamics }_{i, t-j}+e_{i, t}
\end{aligned}
$$

where $M_{i}$ is real imports of country i, $T F E_{i}$ is total final expenditures, $R P_{i}$ is relative price (import deflator divided by GDP deflator), $\alpha_{i}$ is the equation intercept, ect $t_{i}$ is the coefficient of the error correction term, $a_{1 i}$ and $a_{2 i}$ are the long-term elasticities of import relative to demand and prices respectively, $\beta_{i j}$ are the coefficients relative to short-term dynamics terms (for country $\mathrm{i}$ at time $\mathrm{t}-\mathrm{j})$ and $e_{i t}$ is the error term. We include $\log (\mathrm{RP})$ inside the ECM for ease of exposition, although it may be a stationary variable, whilst $\log (\mathrm{M})$ and $\log (\mathrm{TFE})$ are not.

The equation has been estimated in one step as an error correction model with a SURE approach $^{13}$. We report our results in the appendix. The average (not size weighted) income elasticity is 1.52 , whilst the average (not size weighted) price elasticity is -0.49 (see Table 3 in the column marked $\mathrm{MGE}^{14}$ ). Size weighting by GDP leaves the demand elasticity unchanged but changes the price elasticity to -0.61 . The dynamics of adjustment can be summarised by the

\footnotetext{
${ }^{13}$ It is necessary to take account of the dimension of the error matrix in SURE, and we have done that following Guichard and Lafargue (2001). For a discussion of the issues see Pesaran (2003).

${ }^{14}$ See Pesaran Smith and Im (1996)
} 
average (not size weighted) error correction term of -0.32. It is possible to attach t statistics to these averages, and we do so in Table 3, column MGE. We can see from the appendix, the individually estimated demand elasticities are high for the UK, Italy and France, but not Japan,. Appendix Table 1 shows some other apparent differences across countries as regards the value of this elasticity. For instance Mexico and Spain, have elasticities higher than 2, while income elasticities for Asian countries (Korea, Singapore, Taiwan, Thailand) are closer to 1. The main advanced economies are close to the average. The correlation of the demand elasticity with the scale of the country, as measured by the rank order of their share in imports, is negative at -0.21 and with size measured by GDP at PPPs the correlation is 0.01 . The price elasticities also vary with size, and the correlation with the rank order of trade shares is 0.31 and with country size it is -0.21 . The correlation of coefficients with their rank order of trade shares is interesting, and may reflect a missing variable that is correlated with the level of imports. This systematic relationship of the coefficients with another variable would suggest that pooling these countries would be problematic. In particular, omitting a potentially significant variable - that is not independent of those included - may both bias the coefficient upward and make some coefficients spuriously precise, implying difficulties to impose a justifiable commonality.

There is a sequence of hypotheses that we need to test to look for commonalities. Column 1 of Table 3 records the mean group estimates discussed above along with the synthetic ' $t$ ' statistics implied by the estimates. These parameters can be treated as a reasonable and unbiased estimate of a common underlying structure, but it is useful to test for commonalities. The common way to proceed with panel estimation is to estimate a fixed effect model where we impose all coefficients, including those on dynamic elements as well as the long run effects, to be the same. We report these estimates in column 5 of Table 3. The income and price elasticities are lower than in the SURE system, but the fact that the error correction falls to a very low number indicates some misspecification. Pesaran and Smith (1995) suggest that inconsistent pooling may bias dynamic responses, and that is clearly what we see here, where the fixed effects error correction is at one end of the range of the individual country coefficients, and suggests a much lower overall speed of adjustment. Clearly, a fixed effects explanation of import demand would 
not give us a good basis for understanding trends. In column 2 of Table 3, we report the parameters for a pooled mean group estimator where dynamic elements are allowed to differ but where the error correction, income and relative price terms are assumed to be the same. The results show a sharp decrease in the absolute value of the error correction parameter compared with the MGE case (from -0.32 to -0.04 ). The income elasticity decreases to 1.47 and the relative-price coefficient also declines from -0.49 to -0.24 . As we can see from Table 4 , if we test the restriction involved in either the fixed effects estimator or the pooled mean group in column 2 then it is clear that they imply overly strong restrictions on the freely estimated parameters, and we should reject them. However, we can look at less restricted hypotheses concerning commonalities between countries.

Table 3 - Results of different models

\begin{tabular}{lccccc}
\hline \hline & MGE & PMGE1 & PMGE2 & PMGE3 & Fixed effects \\
& $(1)$ & $(2)$ & $(3)$ & $(4)$ & $(5)$ \\
\hline ect & $-0.32(6.64)$ & $-0.04[-5.50]$ & Country specific & Country specific & $-0.04[-5.44]$ \\
Y & $1.52(15.80)$ & $1.47[20.63]$ & $1.17[63.60]$ & $1.53[43.04]$ & $1.36[20.99]$ \\
RP & $-0.49(7.55)$ & $-0.24[-2.59]$ & $-0.51[-13.02]$ & Country specific & $-0.20[-2.17]$ \\
\hline
\end{tabular}

Notes: MGE: Mean Group Estimates

PMGE1: Pool Mean Group Estimate with constraints on ect, income and relative price elasticities PMGE2: Pool Mean Group Estimate with constraints on income and relative price elasticities PMGE3: Pool Mean Group Estimate with constraints on income elasticities

Pesaran et al (1999) suggests that the biases associated with incorrect pooling of adjustment dynamics can be avoided by testing only for common long-run parameters, and we do this in the remaining columns of Table 3. The third column shows the results for PMGE2 (constraints on the income elasticity and on the relative price elasticity), and the fourth column shows them for PMGE3 (constraints on the income elasticity only). The values of these parameters are different across the different models, and removing the dynamic constraint from PMGE1 in PMGE2 gives us a higher competitiveness elasticity and a lower demand elasticity. Once again when testing these different models against the first one (MGE with all parameters assumed to be countryspecific), all constrained specifications appear to be rejected by a standard likelihood ratio test. 
Table 4 - Tests of different models

\begin{tabular}{lccc}
\hline \hline H0 & H1 & Statistics & Result \\
\hline PMGE1 & MGE & $163.00($ Chi2(63)) & H0 rejected \\
PMGE2 & MGE & $100.50($ Chi2(42)) & H0 rejected \\
PMGE3 & MGE & $50.77($ Chi2(21)) & H0 rejected \\
Fixed effects & MGE & $376.9($ Chi2(84)) & H0 rejected \\
\hline
\end{tabular}

\subsection{Results including FDI in the import equations}

Looking for common parameters in standard models neither gives us systematic evidence of lower demand elasticities, nor are any acceptable commonalities. Our theoretical discussion suggested that, in an imperfectly competitive world, we would see increased FDI as barriers to trade were reduced and as more goods became available, and hence we might expect that this variable would play a role in determining the pattern of imports, and that increased globalisation, as indexed by FDI penetration, would account for some or all of the excess of income demand elasticities. In particular, countries with less FDI may have lower import penetration, and hence countries whose (inward and outward) FDI has grown most rapidly may have their measured demand elasticity made both larger and more precise if we omit this variable (as the omitted variable would be correlated with an included variable). Our theoretical discussion makes it clear that patterns of development in import penetration are unlikely to be uncorrelated with developments in FDI, and hence the omission of these variables would lead to biased and over precise coefficients in our regressions, although in general we cannot be certain whether the bias will always be in the same direction.

In the second part of the empirical evidence, we introduce FDI variables into the specification in order to assess the potential impact on income elasticities and on the accuracy with which they are measured. More precisely, these variables represent the stock of inward and outward FDI in real terms as a percentage of real GDP, where the GDP deflator is used to transform the nominal 
FDI series into real ones. The following specification is used for the estimations of import demand equations with FDI effects:

$$
\begin{aligned}
& \Delta \log \left(M_{i, t}\right)=\alpha_{i}^{\prime}+e c t_{i}^{\prime}\left(\begin{array}{l}
\log \left(M_{i, t-1}\right)-a_{1, i}^{\prime} \log \left(T F E_{i, t-1}\right)-a_{2, i}^{\prime} \log \left(R P_{i, t-1}\right) \\
-a_{3, i}^{\prime} \log \left(F D I_{i, t-1}^{\text {inw }}\right)-a_{4, i}^{\prime} \log \left(F D I_{i, t-1}^{\text {out }}\right)
\end{array}\right) \\
& +\sum_{j} \beta_{i, j}^{\prime} \text { dynamics }_{i, t-j}+e_{i, t}^{\prime}
\end{aligned}
$$

where $F D I^{\text {inw }}\left(F D I^{\text {out }}\right.$ ) are the ratio of the stock of inward (outward) FDI on GDP. Given the growth in these ratios observed in the last 30 years, neither can be seen as stationary variables, and hence they should be included within the equilibrium correction part of our specification.

Table 5 shows the MGE values of the estimation of our relationships one at a time, and the full error correction mechanism, price and demand elasticity results are reported in Appendix Table 2 for comparison with Appendix Table 1. While the income elasticity is broadly equal to the MGE values without FDI, the error correction coefficient is slightly lower and the value of the relative price elasticity increases from -0.49 to -0.37 . Both inward and outward FDI appear to raise imports on average, although the dispersion of estimates across countries is such that in the MGE the average coefficients are not significant. Inward and outward FDI seem to have different effects in different countries. However, adding FDI on its own does not remove the puzzle on high income elasticities when they are freely estimated, although it may allow us to explain why they are different if we exclude this variable. 
Table 5 - Results of different models with FDI

\begin{tabular}{lccccc}
\hline \hline & MGE & PMGE1 & PMGE2 & PMGE3 & Fixed effects \\
& $(1)$ & $(2)$ & $(3)$ & $(4)$ & $(5)$ \\
\hline Ect & $-0.42(-8.03)$ & $-0.12[-10.65]$ & Country specific & Country specific & $-0.04[-5.23]$ \\
Y & $1.53(11.33)$ & $1.33[23.38]$ & $1.27[59.47]$ & $1.24[51.17]$ & $1.36[15.90]$ \\
Rp & $-0.37(3.69)$ & $-0.16[-3.69]$ & $-0.20[-5.82]$ & Country specific & $-0.19[-1.84]$ \\
Inward FDI & $0.08(0.96)$ & Country specific & Country specific & Country specific & $-0.02[0.18]$ \\
Outward FDI & $-0.77(0.35)$ & Country specific & Country specific & Country specific & $0.04[0.40]$ \\
& & & & & \\
\hline
\end{tabular}

Notes: MGE: Mean Group Estimates

PMGE1: Pool Mean Group Estimate with constraints on ect, income and relative price elasticities

PMGE2: Pool Mean Group Estimate with constraints on income and relative price elasticities

PMGE3: Pool Mean Group Estimate with constraints on income elasticities

The standard fixed effects estimator is reported in column 5 of Table 5, and as we can see from Table 6 the imposition of common parameters on all long-run and dynamic terms is clearly invalid. The error correction is once again very low. In this context, the coefficients on FDI are small and insignificant, suggesting that the underlying effects are heterogeneous. Differences in speeds of response to shocks and in particular differences in the speed of adjustment to a new equilibrium clearly differ systematically between countries. The differences between countries in terms of the effects of FDI on imports that we see in these unpooled regressions are large enough for us not to use these in the PMG. In column 2, we report a regression where FDI effects and dynamic terms are allowed to vary between countries but where income and price terms, along with the error correction are assumed to be common. The specification gives a relatively low income elasticity, and it also reduces the price elasticity. It also displays dynamics of response well below the average of the group, and hence the panel set can be presumed to have different dynamics amongst its members, and imposing common dynamics is likely to result in biased parameters (see Pesaran and Smith (1995)). However, this model is also rejected as a constraint on the individual country estimates, as we can see by looking at PMGE1 in Table 6. 
Table 6 - Tests of different models with FDI

\begin{tabular}{lccc}
\hline \hline H0 & H1 & Statistics & Result \\
\hline PMGE1 & MGE & 235.86 (Chi2(63)) & H0 rejected \\
PMGE2 & MGE & 83.66 (Chi2(42)) & H0 rejected \\
PMGE3 & MGE & $22.37($ Chi2(21)) & H1 rejected \\
Fixed effects & MGE & $561.84($ Chi2(84)) & H0 rejected \\
\hline
\end{tabular}

When we remove the common error correction in column 3 of Table 5, the income elasticity remains relatively low and the price elasticity rises somewhat, although it remains below the MGE value, and both are significant. As we can see from Table 6 imposing 2 common coefficients is not statistically acceptable. The income elasticity in PMGE2 remains significantly and noticeably different from 1 . We evaluate a model, PMGE3, where only the demand elasticity is constrained to be the same, and we report the coefficient in column 4 of Table 5 . It is possible to accept that it is a valid imposition, as we can see from Table 6. The average competitiveness elasticity in this panel is -0.27 . Although FDI is not significant for all the countries in the sample, it seems to affect significantly the value of the other estimators by reducing the spurious accuracy of their coefficients that came from excluding a variable that was correlated with the regressor.

Based on this sample, we can derive some tentative conclusions as regards the impact of FDI on import demand and Table 3 in the appendix reports on the significant FDI coefficients. Inward FDI generally has a positive effect on imports and all the significant coefficients are positive for this variable. Inward FDI is very low in Japan, and any increases in it have been associated with major liberalisation of import restrictions, and hence in this country it has a relatively large effect. We would presume that this coefficient would decline as inward FDI rose to international levels. The average coefficient on inward FDI in this regression is 2.1, suggesting that inward FDI does raise imports. Outward FDI has also positive effects on imports overall, with an 
average coefficient of 0.27 . This coefficient is positive and significant in some developed countries (e.g. US, Germany, Italy, Austria, Sweden), while it is negative for some developing countries (e.g. Korea, Singapore or Thailand) as well as Belgium. Thailand has very little outward FDI, and the large coefficient suggest that this variable has moved with general changes in patterns of trade. Singapore and Belgium have large amounts of outward FDI, and they are also both small countries with significant levels of trade with close neighbours. These are just the situations where we would expect outward FDI to reduce the level of imports as it probably reduces production at home for the foreign market.

\section{CONCLUSION}

It is common to observe that demand elasticities in trade equations for imports are implausibly large, and that they differ between countries. Both of these present us with problems, as they imply trade will rise without bound as a proportion of GDP, and that a steady state for the world economy would be difficult to attain, as imports would grow at different rates in different countries. In this paper we have investigated import demand in a large range of countries. Our first estimates include only domestic demand, relative prices and the dynamics of adjustment to the long-run equilibrium. We tested to see if we could impose the same demand, price and adjustment speed parameters, and we found it was statistically impossible to do so. Even when we allowed the dynamics to differ between countries we were not able to impose common demand and price elasticities, and the observed demand elasticity remained high, even when we allowed price elasticities to differ between countries..

We proceeded to estimate an equation that included the ratios of outward and inward FDI to GDP as additional openness and globalisation indicators. These variables appear to have removed the spurious accuracy with which we were measuring demand elasticities. The variety 
of coefficients and effects, which differ between countries, means that we cannot statistically justifiably impose a common set of coefficients on inward and outward FDI in all countries, and when we do so the coefficients on FDI are not significant. Given that even the sign of FDI effects is not clear from our theoretical discussion, this does not surprise us. However, overall inward and outward FDI appear to raise imports. It is also not possible to impose common dynamics on our equations, but it is possible to impose common income effects once we allow for inward and outward FDI as a determinant of import propensities, and the income elasticity of demand is reduced to 1.24 , well below the estimated elasticities we observe either in single country regressions reported in Barrell and te Velde (2002) or those derived in panels when we do not include inward and outward FDI. Hence we demonstrate that the inclusion of the ratio of outward and inward FDI as a percent of GDP resolves most of these puzzles we face with import demand.

There is clear evidence that models of import demand that do not take account of both the importance of globalisation factors as indexed by inward and outward FDI to GDP and of the heterogeneity of the impacts of relative prices and FDI produce upwardly biased estimates of the income elasticity of demand. However, we would argue that there is need for further research to understand both the diversity of FDI effects between countries and the role of other forces driving globalisation such as the formation of regional trading systems, which raise imports as a proportion of GDP. 


\section{References}

Barrell, R. and A. Choy (2003). Economic Research and Decision Making. Festschrift for Pentti Vartia, ETLA, Finland: 45-68

Barrell, R. and D.W. te Velde (2002) Evolving patterns in manufactures import demand in the European Union. An empirical investigation of 10 European countries. German Economic Review

Barrell, R., and N. Pain (1997). European Integration and Foreign Direct Investment: the UK Experience. National Institute Economic Review 160.

Barrell, R., and N. Pain (1999). Trade restraints and Japanese direct investment flows. European Economic Review 43(1): 29-45

Coyle, D. (1998). The Weightless World: Strategies for Managing the Digital Economy. MIT Press.

Dixit, A.K. and J.E. Stiglitz (1977). Monopolistic competition and optimum product diversity. American Economic Review 67: 297-308.

Fagerberg, J. (1996). Technology and competitiveness. Oxford Review of Economic Policy 12(3): 39-49.

Griffith, R., (1999). Using the ARD establishment level data to look at foreign ownership and productivity in the UK. The Economic Journal 109: F416-F442.

Guichard, S., and J.P. Lafargue (2001). Comparaison de la formation des salaires dans un panel de pays industrialises. Economie et Prevision 147: 37-50.

Hsiao, C., (2003). Analysis of Panel Data. $2^{\text {nd }}$ edition. Cambridge University Press

Krugman, P.R. (1989). Differences in Income Elasticities and Trends in real exchange rates, in P.R. Krugman (1995). Currencies and Crises, MIT, Cambridge. 
Krugman, P.R. (1995). Increasing Returns, Imperfect Competition and the Positive theory of International Trade. In Grossman, G. and K. Rogoff (eds.). Handbook of International Economics. Vol. 3. Amsterdam: North Holland.

Magnier, A. and J. Toujas-Bernate (1994). Technology and trade: Empirical Evidences for the Major Five Industrialized Countries. Weltwirtschaftliches Archiv 3: 494-520.

Markusen, J. R. (1983). Factor movements and commodity trade as complements. Journal of International Economics 13: 341-356.

Mundell R.A. (1957). International trade and factor mobility. American Economic Review 47: 321-335.

OECD (2002). The relationship between trade and foreign direct investment: a survey. OECD Working Paper TD/TC/WP(2002)14/FINAL

Pain, N. and K. Wakelin. (1998). Export performance and the role of foreign direct investment. The Manchester School Supplement 66: 62-88.

Pesaran, M H, Shin, Y. and R.P. Smith (1999). Pooled mean group estimation of dynamic heterogeneous panels. Journal of the American Statistical Association 94: 621-634

Pesaran, H., R.P. Smith, and K.S. Im (1996). Dynamic Linear Models for Heterogenous Panels. In L. Mátyás and P. Sevestre (eds), The Econometrics of Panel Data. Kluwer

Pesaran, M-H, (2003). Estimation and Inference in Large Heterogeneous Panels with Cross Section Dependence. DAE working paper 0305.

Pesaran, M-H., Smith, R., (1995). Estimation of long-run relationships from dynamic heterogeneous panels. Journal of Econometrics 68: 79-114.

Tirole, J. (1988). The Theory of Industrial Organization. MIT press, Cambridge, Massachusetts.

UNCTAD (1996). World Investment Report 1996. United Nations.

UNCTAD (2003). World Investment Report 2003. United Nations. 


\section{APPENDIX}

Table A1 - SURE estimates (without FDI)

\begin{tabular}{|c|c|c|c|c|}
\hline & $\Delta \mathrm{Y}$ & ect & $\mathrm{Y}$ & $\mathrm{RP}$ \\
\hline United States & $2.40[6.94]$ & $-0.37[-6.22]$ & $1.65[27.92]$ & $-0.70[-5.52]$ \\
\hline Germany & 2.13 [8.39] & $-0.37[-6.22]$ & $1.60[11.41]$ & $-0.31[-2.30]$ \\
\hline United Kingdom & 0.91 [6.18] & $-0.30[-3.56]$ & $1.85[10.72]$ & $-0.32[-2.44]$ \\
\hline Japan & 0.14 [1.64] & $-0.13[-3.93]$ & $0.63[2.17]$ & $-0.78[-3.90]$ \\
\hline France & 2.25 [10.29] & $-0.74[-7.16]$ & $1.79[22.00]$ & $-0.36[-5.76]$ \\
\hline China & 0.32 [2.20] & $-0.03[-0.82]$ & 1.66 [3.12] & $-0.66[-1.00]$ \\
\hline Italy & 3.97 [16.21] & $-0.52[-7.09]$ & $1.81[15.04]$ & $-0.29[-4.18]$ \\
\hline Canada & 1.55 [3.68] & $-0.11[-1.45]$ & 1.54 [4.93] & $-1.00[-1.57]$ \\
\hline Netherlands & 1.90 [12.87] & $-0.34[-3.54]$ & $1.63[17.30]$ & $-0.33[-3.90]$ \\
\hline Hong Kong & 1.43 [7.97] & $-0.48[-1.49]$ & 1.21 [31.68] & $-0.85[-6.65]$ \\
\hline Belgium & $0.52[5.22]$ & $-0.29[-2.55]$ & $1.43[29.80]$ & $-0.52[-11.56]$ \\
\hline Mexico & $1.36[4.40]$ & 0.13 [1.57] & $2.28[10.45]$ & $-1.24[-3.00]$ \\
\hline Spain & 2.36 [14.53] & $-0.30[-4.32]$ & $2.49[15.66]$ & $-0.29[-2.77]$ \\
\hline South Korea & 0.56 [7.87] & $-0.49[-4.87]$ & 1.12 [17.31] & $-0.64[-5.85]$ \\
\hline Singapore & 0.94 [18.12] & $-0.08[-0.76]$ & 1.32 [3.68] & $0.04[0.04]$ \\
\hline Taiwan & 1.32 [12.31] & $-0.61[-7.30]$ & $1.17[42.30]$ & $-0.47[-5.99]$ \\
\hline Switzerland & 1.62 [4.37] & $-0.11[-1.03]$ & $1.55[1.85]$ & $-0.60[-1.99]$ \\
\hline Austria & $0.90[17.74]$ & $-0.57[-7.24]$ & 1.63 [3.69] & $-0.44[-2.83]$ \\
\hline Australia & 1.62 [3.69] & $-0.57[-7.24]$ & $1.71[28.05]$ & $-0.49[-4.73]$ \\
\hline Sweden & $1.00[14.80]$ & $-0.39[-4.14]$ & 1.75 [20.67] & $-0.33[-3.99]$ \\
\hline Thailand & 1.99 [7.47] & $-0.20[-2.64]$ & $1.17[16.35]$ & $-0.25[-0.87]$ \\
\hline Brazil & $0.34[0.84]$ & $-0.73[-7.15]$ & $0.52[9.06]$ & 0.05 [5.95] \\
\hline
\end{tabular}


Table A2 - SURE estimates (with FDI - FDI coefficients omitted)

\begin{tabular}{lcccc}
\hline \hline & $\Delta \mathrm{Y}$ & $\mathrm{ect}$ & $\mathrm{Y}$ & $\mathrm{RP}$ \\
\hline United States & $2.39[6.51]$ & $-0.48[-6.71]$ & $1.45[17.97]$ & $-0.63[-5.85]$ \\
Germany & $2.22[10.35]$ & $-0.66[-8.27]$ & $1.30[19.99]$ & $-0.10[-1.90]$ \\
U K & $0.98[6.89]$ & $-0.44[-4.36]$ & $1.77[14.35]$ & $-0.29[-2.90]$ \\
Japan & $0.17[1.94]$ & $-0.23[-4.40]$ & $0.25[0.86]$ & $-0.30[-3.02]$ \\
France & $2.16[10.62]$ & $-0.88[-9.07]$ & $1.56[19.82]$ & $-0.11[-1.42]$ \\
China & $0.47[2.81]$ & $-0.02[-0.60]$ & $0.89[0.48]$ & $1.23[0.37]$ \\
Italy & $3.83[16.51]$ & $-0.66[-9.07]$ & $1.58[14.08]$ & $-0.19[-2.86]$ \\
Canada & $1.66[3.90]$ & $-0.08[-1.18]$ & $2.70[1.61]$ & $-0.78[-1.01]$ \\
Netherlands & $1.84[12.49]$ & $-0.41[-3.28]$ & $1.68[7.06]$ & $-0.40[-4.28]$ \\
Hong Kong & $1.42[7.78]$ & $-0.41[-1.23]$ & $1.21[25.17]$ & $-0.82[-4.47]$ \\
Belgium & $0.48[4.69]$ & $-0.31[-2.62]$ & $1.36[13.91]$ & $-0.51[-10.76]$ \\
Mexico & $1.29[4.17]$ & $0.13[1.49]$ & $2.44[3.17]$ & $-1.28[-2.54]$ \\
Spain & $2.31[14.17]$ & $-0.32[-4.45]$ & $2.28[9.27]$ & $-0.28[-2.50]$ \\
South Korea & $0.49[6.69]$ & $-0.52[-5.18]$ & $0.95[7.76]$ & $-0.76[-6.27]$ \\
Singapore & $0.88[19.72]$ & $-0.54[-3.73]$ & $1.16[43.64]$ & $-0.64[-14.31]$ \\
Taiwan & $1.37[13.56]$ & $-0.79[-8.74]$ & $1.31[25.21]$ & $-0.35[-4.79]$ \\
Switzerland & $1.74[4.64]$ & $-0.39[-2.68]$ & $2.73[6.21]$ & $-0.74[-9.11]$ \\
Austria & $0.89[16.43]$ & $-0.35[-4.23]$ & $1.41[11.44]$ & $-0.07[-0.38]$ \\
Australia & $1.44[3.06]$ & $-0.59[-6.55]$ & $1.75[9.85]$ & $-0.57[-4.37]$ \\
Sweden & $1.04[14.20]$ & $-0.38[-3.97]$ & $1.99[10.37]$ & $-0.41[-2.94]$ \\
Thailand & $1.91[6.08]$ & $-0.27[-3.42]$ & $1.29[15.24]$ & $-0.26[-0.87]$ \\
Brazil & $0.43[1.04]$ & $-0.73[-7.07]$ & $0.52[7.18]$ & $0.05[5.41]$ \\
\hline & & & & \\
\hline
\end{tabular}


Table A3 - Significant Effects of RP and FDI in PMGE3

\begin{tabular}{|c|c|c|c|}
\hline & $\overline{\mathrm{RP}}$ & Inward FDI & Outward FDI \\
\hline United States & $-0.77[-5.44]$ & n.s. & $0.82[3.20]$ \\
\hline Germany & $-0.12[-2.46]$ & n.s. & 0.42 [8.22] \\
\hline United Kingdom & $-0.66[-3.10]$ & n.s. & n.s. \\
\hline Japan & $-0.54[-2.46]$ & 3.88 [1.89] & n.s. \\
\hline France & n.s. & $0.79[4.54]$ & n.s. \\
\hline China & n.s. & n.s. & n.s. \\
\hline Italy & $-0.26[-3.94]$ & n.s. & 2.06 [4.67] \\
\hline Canada & n.s. & n.s. & n.s. \\
\hline Netherlands & $-0.34[-2.42]$ & n.s. & 0.14 [1.89] \\
\hline Hong Kong & $-0.75[-2.94]$ & n.s. & n.s. \\
\hline Belgium & $-0.52[-10.95]$ & $0.20[2.69]$ & $-0.20[-2.57]$ \\
\hline Mexico & n.s. & 1.68 [1.73] & n.s. \\
\hline Spain & $-0.35[-1.66]$ & $1.00[3.66]$ & n.s. \\
\hline South Korea & $-0.54[-7.44]$ & $1.02[1.58]$ & $-1.10[-1.43]$ \\
\hline Singapore & $-0.54[-7.44]$ & n.s. & $-0.47[-3.79]$ \\
\hline Taiwan & $-0.29[-4.08]$ & n.s. & n.s. \\
\hline Switzerland & $-0.71[-3.98]$ & n.s. & n.s. \\
\hline Austria & n.s. & n.s. & $1.08[2.30]$ \\
\hline Australia & $-0.47[-2.96]$ & $1.58[1.70]$ & n.s. \\
\hline Sweden & n.s. & n.s. & 0.22 [1.33] \\
\hline Thailand & n.s. & n.s. & -13.77 [1.80] \\
\hline Brazil & n.s. & n.s. & n.s. \\
\hline
\end{tabular}




\section{European Central Bank working paper series}

For a complete list of Working Papers published by the ECB, please visit the ECB's website (http://www.ecb.int)

466 “Regulated and services' prices and inflation persistence” by P. Lünnemann and T. Y. Mathä, April 2005.

467 "Socio-economic development and fiscal policy: lessons from the cohesion countries for the new member states" by A. N. Mehrotra and T. A. Peltonen, April 2005.

468 "Endogeneities of optimum currency areas: what brings countries sharing a single currency closer together?" by P. De Grauwe and F. P. Mongelli, April 2005.

469 "Money and prices in models of bounded rationality in high inflation economies" by A. Marcet and J. P. Nicolini, April 2005.

470 "Structural filters for monetary analysis: the inflationary movements of money in the euro area" by A. Bruggeman, G. Camba-Méndez, B. Fischer and J. Sousa, April 2005.

47I "Real wages and local unemployment in the euro area" by A. Sanz de Galdeano and J. Turunen, April 2005.

472 "Yield curve prediction for the strategic investor" by C. Bernadell, J. Coche and K. Nyholm, April 2005.

473 "Fiscal consolidations in the Central and Eastern European countries" by A. Afonso, C. Nickel and P. Rother, April 2005.

474 "Calvo pricing and imperfect common knowledge: a forward looking model of rational inflation inertia" by K. P. Nimark, April 2005.

475 "Monetary policy analysis with potentially misspecified models" by M. Del Negro and F. Schorfheide, April 2005.

476 "Monetary policy with judgment: forecast targeting” by L. E. O. Svensson, April 2005.

477 "Parameter misspecification and robust monetary policy rules" by C. E. Walsh, April 2005.

478 "The conquest of U.S. inflation: learning and robustness to model uncertainty" by T. Cogley and T. J. Sargent, April 2005.

479 "The performance and robustness of interest-rate rules in models of the euro area" by R. Adalid, G. Coenen, P. McAdam and S. Siviero, April 2005.

480 "Insurance policies for monetary policy in the euro area" by K. Küster and V. Wieland, April 2005.

481 "Output and inflation responses to credit shocks: are there threshold effects in the euro area?" by A. Calza and J. Sousa, April 2005.

482 "Forecasting macroeconomic variables for the new member states of the European Union" by A. Banerjee, M. Marcellino and I. Masten, May 2005.

483 "Money supply and the implementation of interest rate targets" by A. Schabert, May 2005.

484 "Fiscal federalism and public inputs provision: vertical externalities matter" by D. Martínez-López, May 2005. 
485 "Corporate investment and cash flow sensitivity: what drives the relationship?" by P. Mizen and P. Vermeulen, May 2005.

486 "What drives productivity growth in the new EU member states? The case of Poland" by M. Kolasa, May 2005.

487 "Computing second-order-accurate solutions for rational expectation models using linear solution methods" by G. Lombardo and A. Sutherland, May 2005.

488 "Communication and decision-making by central bank committees: different strategies, same effectiveness?" by M. Ehrmann and M. Fratzscher, May 2005.

489 "Persistence and nominal inertia in a generalized Taylor economy: how longer contracts dominate shorter contracts" by H. Dixon and E. Kara, May 2005.

490 "Unions, wage setting and monetary policy uncertainty" by H. P. Grüner, B. Hayo and C. Hefeker, June 2005.

49| "On the fit and forecasting performance of New-Keynesian models" by M. Del Negro, F. Schorfheide, F. Smets and R. Wouters, June 2005.

492 "Experimental evidence on the persistence of output and inflation" by K. Adam, June 2005.

493 "Optimal research in financial markets with heterogeneous private information: a rational expectations model” by K. Tinn, June 2005.

494 "Cross-country efficiency of secondary education provision: a semi-parametric analysis with non-discretionary inputs" by A. Afonso and M. St. Aubyn, June 2005.

495 "Measuring inflation persistence: a structural time series approach" by M. Dossche and G. Everaert, June 2005.

496 "Estimates of the open economy New Keynesian Phillips curve for euro area countries" by F. Rumler, June 2005.

497 "Early-warning tools to forecast general government deficit in the euro area: the role of intra-annual fiscal indicators" by J. J. Pérez, June 2005.

498 "Financial integration and entrepreneurial activity: evidence from foreign bank entry in emerging markets" by M. Giannetti and S. Ongena, June 2005.

499 "A trend-cycle(-season) filter" by M. Mohr, July 2005.

500 "Fleshing out the monetary transmission mechanism: output composition and the role of financial frictions" by A. Meier and G. J. Müller, July 2005.

501 "Measuring comovements by regression quantiles" by L. Cappiello, B. Gérard, and S. Manganelli, July 2005.

502 "Fiscal and monetary rules for a currency union" by A. Ferrero, July 2005

503 "World trade and global integration in production processes: a re-assessment of import demand equations" by R. Barrell and S. Dées, July 2005. 
